УДК УДК 171: 177(177.5/177.72)

DOI 10.35423/2078-8142.2020.2.2.04

I. С. Жовтоног, аспірант Центру гуманітарної освіти Національної академї наук Украӥни, м. Київ, Украӥна e-mail: irazhovtonoh@gmail.com ORCID: https://orcid.org/0000-0002-9702-5903

\title{
МІСЦЕ І СМИСЛ КОМУНІКАЦЇ̈ У ФІЛОСОФІЇ ІНШОГО
}

У статті досліджено джерела концепиії комунікації, щзо сформувалась у філософії «Іншого». Виявлено особливості побудови дискурсу з «Іниим» на основі філософії діалогу. Взаємодія $з$ «Іншим» тут здійснюється через артикуляцію «Іншого», звернення $і$ відповідь на звернення «Іншого», інтенційність, рефлексивність, взаємну направленість. Визначено специфіку орієнтації на особистісну, індивідуальну основу спілкування, щьо здійснюється у персоналістській філософії. Концепти відкритості, чутливості, небайдужості, відповідальності є визначальними для побудови комунікацї̈ у персоналістській філософії. Визначено критерії інтерпретації чуттєвих даних «Іншого» на підставі образу, поведінки, накопиченого життєвого досвіду, які розроблюються у сочіологічній феноменологіі. Формування сочіальних зв'язків відбувається на основі сприйняття мотивів, поведінки і реакцій «Іншого» у повсякденності. Механізми соціального пізнання, успішної взаємодії $з$ «Іншими» та самопізнання розкриваються у сучасних теоріях комунікаціі. Вони поглиблюють розуміння сочіального пізнання через ставлення до «Іншого» у різних процесах, від емпатії до членства у групі. Комунікативний простір досліджено як сферу діяльності, щзо поєднує у собі взаємозв'язки внутрішніх мотивів і особистісних установок індивіда із загальними цінностями, ідеалами й нормами інших людей. Перспектива дослідження обраної проблеми охоплює сучасні розробки концепції «Іншого», які поглиблюють розуміння того, щуо такі механізми соціального пізнання, як емпатія чи член-

(c) Жовтоног I. C., 2020 
ство у групі, розкривають значення успішної взаємодї з іншими у сочіальному світі.

Ключові слова: комунікація з Іншим, інтенційність, рефлексивність, взаємозамінюваність точок зору, укоріненість, самоідентифікачія, емпатія.

Поглиблення міжцивілізаційних протистоянь, етнічних протиріч, конфесійних суперечностей у сучасному світі корелюється 3 часто домінуючою суспільною комунікативною установкою, яка пов'язана 3 намаганням нав'язати виключну правоту власної позиції. Це загострення глобальних конфліктів спричинене неприйняттям «Іншості», невизнанням права на відмінності та особливості. Сторони конфлікту своєю чергою постають як закриті цілісності, суб'єктивні світи, які не здатні почути та зрозуміти одне одного внаслідок відсутності дієвої комунікації. Таким чином, завдання статті визначається необхідністю розкриття значення комунікації, що сформувалося у філософії «Іншого».

Ідея комунікації з «Іншим» набула свого розвитку та особливостей у різноманітних філософських напрямах, школах і ученнях. Так, зокрема, детальне дослідження особливостей побудови діалогу 3 «Іншим», таких як артикуляція «Іншого», звернення і відповідь на звернення «Іншого», інтенційність, рефлексивність, взаємна направленість, здійснюється представниками філософії діалогу. Емануель Левінас у праці «Тотальність і нескінченне» формулює парадигму значень «Іншого», що розкривається завдяки спілкуванню. Спілкування 3 «Іншим» досліджуються Левінасом у взаємовідношенні двох суб'єктивностей як трансцендування «один-дляІншого», «обличчя-до-обличчя», «людини-до-людини». «Справді, мова здійснює зв'язок такого роду, що складові іiі елементи не поєднуються один з одним, і що Інший, не зважаючи на цей зв'язок, залишається трансцендентним по відношенню до самототожного. Відношення самототожного й Іншого, іншими словами, метафізичне відношення, здійснюється спочатку у вигляді мови, де самототожний, сконцентрований у самості свого «я», - неповторної, автохтонної істоти, - виходить за власні межі» [2, с. 7]. 
Важливим для Левінаса є почути і зрозуміти «Іншого» без намагання зіставити із собою, зрівняти, накинути свої особистісні характеристики «Іншому». Під час розмови виникають такі взаємовідносини, завдяки яким кожен зі співрозмовників, зберігаючи власну цілісність, самобутність своєї точки зору і світоглядної позиції, - водночас залишає позаду власні установки для того, щоб відповісти «Іншому» як трансцендентному. Зокрема, Левінас зауважує, що головний зміст розмови розкривається у діалозі, під час самої комунікації. Звертатись до «Іншого» і формулювати окремі слова чи складати з них речення, для Левінаса, означає розуміти $i$ схоплювати «Іншого» так, як він себе виражає і позиціонує, таким яким він $є$ у власній «самості». «Відношення до Іншого, або Дискурс, є відношенням «неалергічним», етичним, але воно ж, добровільно прийняте, є також і навчанням. Однак, таке научіння не повертає нас до маєвтики. Воно приходить ззовні і приносить із собою те, чим я до цього не володів» [2, с. 15].

Таким чином, дискурс, який у вільній формі виникає між особистостями, розкриває перед ними раніше невідомі, неусвідомлені і незрозумілі один для одного світоглядні орієнтири i, тим самим привносячи нове знання, змінює ці особистості. Тобто діалог, в якому учасники слухають один одного, формулюють запитання, обмінюються думками, без нав'язування зовнішніх для них принципів, має у підсумку відкрити перед співрозмовниками раніше невідоме одне про одного, й завершитись порозумінням.

Дискурс Левінаса також пов'язаний з поняттям сенсу, адже під час розмови «Інший» кожне вимовлене слово чи фразу наділяє власним значенням. Такий сенс, привнесений у слово і промовлений «Іншим», формується на основі життєвого досвіду, звичаїв i моральнісних переконань. У діалозі відбувається взаємодія сенсів, якими кожен зі співрозмовників означує свої слова і речення i, таким чином, має місце створення вже зовсім нових смислів, породжених спільною комунікацією.

Розвиваючи ідеї філософії діалогу, Мартин Бубер розкриває два способи взаємодії людини 3 іншою особистістю. Людина або вибудовує свої зв'язки зі світом на основі відношення до світу «Я Воно», де всі інші люди у такому світі є зовнішніми, чужими, позбавленими власної індивідуальності об'єктами. Відповідно, й своє 
відношення і спосіб спілкування 3 «нншими» людина засновує на основі сили, влади, нав'язування власних світоглядних орієнтирів. Для такого типу комунікації $є$ властивою інституційна поведінка. Обираючи інший спосіб власної взаємодії зі світом, на основі концепту «Я - Ти», людина формує своє ставлення до «Інших» як рівних, творчих, самодостатніх особистостей. Важливими при такому спілкуванні 3 іншими людьми є почуття. «Почуття - це те, що «всередині»: тут людина живе і відпочиває від своєї діяльності в інститутах. Тут зацікавленому погляду постане цілий спектр емоцій; людина потурає своїм симпатіям і антипатіям, віддається задоволення, а також страждань, намагаючись в останньому не заходити надто далеко. Тут вона у себе вдома і може розслабитися в кріслі-гойдалці» [1, с. 12].

Людські відносини і взаємність між людьми розкриваються завдяки мові, спілкуванню і комунікації. Саме у словах, запитаннях і відповідях досягають своєї завершеності взаємостосунки між людською особистістю й «Іншим». Під час комунікації сформульоване і вимовлене людиною слово, із вкладеним у нього змістом, значенням і сенсом, спрямоване на розкриття, схоплення і розуміння цього значення «Іншим». «Тут, і тільки тут моменти, відносини, пов'язує стихія мови, в яку вони занурені. Тільки тут основне слово, зберігаючи незмінною свою форму, спрямовується до співрозмовника і відбивається від нього, звернення і відгук живуть всередині» [1, с. 22]. Через відповідь, надану «Іншим», відбувається виявлення смислів такої взаємодії, їх усвідомлення i, як наслідок, взаєморозуміння. Учасники комунікачії, обмінюючись значеннями, смислами й ідеями, вкладеними у слова, словосполучення й речення, пізнають «Іншого», $i$, завдяки «Іниому», самих себе.

Філософи-екзистенціалісти демонструють персоналістську концепцію особистісного спілкування на основі відкритості, чутливості, небайдужості, відповідальності у відношенні до «Іншого». У четвертій частині книги «Буття і Ніщо», розділі 3 назвою «Свобода - перша умова дії» Жан-Поль Сартр вагоме значення надає пізнанню «Іншого» і розкриттю власних можливостей індивіда за допомогою мови. Він звертає увагу, що слова - це елементи індивідуальної реальності, зі своєю історією виникнення і формування, 
3 унікальним значенням і смислом. Навіть якщо люди не мають значного впливу на розвиток мови, проте саме комунікації, обговорення й діалоги, побудовані на основі мови, були і лишаються рушійними фактами соціальних змін. Водночас, не саме слово, хоч би яким вживаним воно було, наприклад, місцевий діалект чи говір, а слово у реченні, точніше промовлене під час розмови слово, $\epsilon$ складовою комунікації. Хоча може й здаватися, що слова є самостійними, проте їх інтерпретують лише як складові речень. «Але, якщо слова начебто живуть тоді, коли проектують семантичний чи морфологічний фільм, вони не доходять аж до того, щоб конституювати речення; слова - тільки сліди проходу речень, так само як і шляхи - тільки сліди проходу прочан і караванів» [4, с. 703].

Лише коли відбувається розмова слова стають справді взаємопов'язаними, підтримують одне з одним зв'язок, взаємно поєднуються або відштовхуються завдяки об'єднанню, синтезу, створеному мовцем. Без мовця, промовця, «Іншого», який говорить, мовлення і сам сенс комунікації розпадаються, втрачають свій сенс, кожне слово починає існувати самостійно, як наслідок втрачається єдність, розсипаючись між непоєднувальними значеннями слів. Тільки тоді, коли слово вживається у процесі живої комунікації, як невіддільна складова того контексту, ситуації в якій ведеться розмова, воно стає складовою цілісної частини. Лише завдяки свободі мовця вільно обирати слова, створювати речення i надавати їм власні значення мова Іншого реалізується як комунікація. «Цілі речення, точнісінько як слова, не існують до вживання, яке зроблять із них. Це просто загальники, якщо читач дивиться на них зовні, й відбудовує зміст вступу, переходячи від речення до речення, проте ці речення втрачають свій банальний, узвичаєний характер. Якщо так, тоді ні слова, ні синтаксис, ні готові фрази не існують до використання, яке зроблять із них» [4, с. 702]. Слово не може існувати як знак, графічне позначення, чи окрема форма, воно вживається лише у тісному зв'язку, переплетенні з тим середовищем, тими обставини й атмосферою, в якій промовляється. Такими обставинами можуть бути час, коли відбувається розмова, місце, де вона ведеться, сприятлива або навпаки негативна ситуація у місті, загальні настрої у країні в цілому. Усі ці фактори є важливими для усвідомлення сенсу вимовлених «Іншим» слів. Так, 
достатньо лише побачити занепокоєння на обличчі «Іншого» перед тим, як почати говорити, щоб вже крізь призму контексту, в якому знаходиться «Інший», окреслити й інтерпретувати, розшифрувати й зрозуміти «Іншого». Розуміти слова «Іншого» у контексті речення означає ще й врахувати ті першопочаткові бажання, прагнення $\mathrm{i}$ цілі, що панують під час розмови, і досягнення яких ставить «Інший» собі за мету. Зрозуміти «Іншого», отже, осягнути те, що хоче «Інший» сказати, усвідомити те значення, яке надано словам і заглибитись у ту реальність, яку проживає «Інший», промовляючи. «Зрозуміти речення мого співрозмовника - ие, фактично, зрозуміти те, щзо він «хоче сказати», тобто підтримати його рух трансцедентності, вкинутися разом із ним до можливостей, до цілей і повернутися згодом до сукупності організованих засобів, щоб зрозуміти їх через їхню функцію та мету» [4, с. 702]. Основа мовлення «Іншого» - у самому «Іншому», чуттєвих даних, образі, поведінці, досвіді.

Схоплення істинного значення речення, саме того, яке хотів передати своєю мовою «Інший», підпорядковує собі всі інші смисли і значення, які відкриваються у мові. Але ці супутні смисли, висловлені «Іншим», не втрачають свого значення. «Розуміння справжнього значення, тобто саме того, яке хотів висловити мовець, може відкинути в затінок, або підпорядкувати решту значень, проте не знищити їх» [4, с. 705].

Сама мова постає вільним проектом у мовленні «Іншого», який, водночас, має свої сформульовані закони. Власне, ці закони $є$ дієвими, такими, що впливають на всю структуру речення, вимовленого «Іншим», лише за умови першопочаткової єдності й синтезу його складників. «Речення», як подія, містить у самому собі закони своєї організації, і саме у вільному проекті означення між словами можуть виникнути законні, тобто граматичні, зв'язки» [4, с. 705].

Проте, будь-які закони мови не можуть існувати чи чинити дію доти, доки висловлювання не буде сформульованим і промовленим «Іншим». Висловлювання репрезентується як вільний проект означення, тобто той, який володіє свободою вибору значення й інтерпретується, або ж пояснюється на основі всієї ситуації у ці- 
лому. Такий проект висловлювання охоплює контекст і обставини, в яких знаходиться «Інший». Первинною є ситуація, на підгрунті або ж підвалинах якої стає зрозумілим значення висловлювання «Іншого». Це значення не надається як фундаментальне, а визначається як вільнообрана ціль, досягнення якої через мовлення ставить собі за мету «Інший».

Водночас, вагомого значення Сартр надає вмінню слухати i чути вимовлене «Іншим». Якщо той, хто говорить, тільки обирає значення і схоплює порядок слів тільки тією мірою, якою створює його, і сприймає ті значення, які самостійно надає власному мовленню, то той, хто слухає розмову, від самого початку проектується, звертається, входить до співрозуміння можливостей «Іншого» та усвідомлює почуте на основі власного досвіду.

Проект феноменологічної соціології відкриває критерії інтерпретації чуттєвих даних «Іншого» на підставі образу, поведінки, отриманого життєвого досвіду. Сприйняття мотивів, поведінки і реакцій індивідів у повсякденності стали предметом дослідження соціальних феноменологів. Поль Рікер у праці «Сам як Інший» заглиблюється у семантичний аналіз дискурсу «Я - Інший». Він досліджує питання діалогічності як ресурсу мови й комунікації, що розкриває взаємозв'язок між «Я» та «Іншим». «Інший», ставлячи запитання, конституює співрозмовника як такого, щэо здатний давати відповідь, зумовлює його відповідальність .

Під час діалогу змінюються не лише ролі мовця й слухача, а й семантичне значення кожного з його суб'єктів. Зокрема, той, хто звертається до свого співрозмовника як «Ти», водночас розуміє, що ця особа здатна визначити себе і як «Я»: «Обмін особовими займенниками у цьому відношенні $є$ показовим; коли я кажу «ти» комусь іншому, він розуміє «я» як відносне до нього самого. Коли він звертається до мене у другій особі, я себе розумію як такого, кого торкаються в першій особі; зворотність стосується водночас ролей того, хто говорить, і того, до кого мова звернена, а також здатності визначати себе самим собою і в особі того, кому призначається дискурс, й особи того, ким він призначається» [3, с. 231]. Тобто, у дискурсі його учасники здатні варіювати свою функцію від активного мовця до слухача, від того, ким висловлене мовлення, до того, кому воно спрямоване, і навпаки. Незамінність «Іншого» у комуні- 
кації як того, без кого діалог не здатен відбутися взагалі, визначає «Іншого» як особистість. Як підсумок, у практиці дискурсу незамінність «Іншого» означає незмінність, укоріненість, приналежність цієї особи з ії власною індивідуальністю конкретному місцю, часу і тому значенню, яке вона має для світу навколо. «Ця вкоріненість сприяє тому, що я не залишаю свого місця і не спростовую розрізнення між «тут» і «там», навіть коли в уяві і за допомогою симпатії ставлю себе на місце іншого» [3, с. 231]. Поль Рікер розширює значення мовної комунікації до більш широких практик соціальних взаємозв'язків, які подібно до мови пов'язують взаємозалежність тих значень, що несе кожен з учасників комунікації 3 незамінністю їх як особистостей. Такими є соціальні інститути, де дії кожного зумовлюються правами та обов'язками. «Те, чого мова вчить саме як практика, верифікується усіма практиками. Провідники дії і ті, на кого дії спрямовані, вступають у відношення обміну, які, подібно до мови, виявляють себе в зворотності ролей і незамінності осіб» [3, с. 231]. Очінювання «Іншого» як самого себе $i$ себе як «Іншого», самоідентифікація, визнання за «Іншим» його «я», укоріненості і незамінності іншої людини, засвідчує рівність учасників комунікації на соціальному рівні.

Альфред Шюц, досліджуючи індивідуальну свідомість, обгрунтовує формування соціальних зв'язків на основі комунікації. Засадничим елементом цього вчення є поняття мотивів, на основі яких він вирізняє два центральних плани: «для того, щоб» і «тому, що». Якщо мотив «для того, щоб» відноситься до майбутнього часу і слугує своєрідною метою, проектом, то мотив «тому, що» відповідає минулому часу, і є причиною рефлексії над уже здійсненим. Ці два мотиви пов'язані між собою і взаємозумовлюють одне одного, адже реалізація майбутніх дій так чи інакше залежить від причини, яка сприяла такій реалізації. «Фактично є правомірним говорити про власну структуру мотиваційної релевантності, і що всередині цієї структури знов-таки слід віднайти дві форми: «свобідну» та «зумовлену». Перша $є$ визначеним начерком дії, майбутнім ланцюгом мотивацій, друга - біографічною, визначеною «настановою» [5, с. 226]. 
Крім того, взаємність мотивів грунтується на взаємності очікуваної поведінки з боку «Іншого», що відкриває більше можливостей взаєморозуміння одне одного, зокрема і під час комунікації. Під час прочесу комунікації ї̈ учасники користуються конструктами очікуваної поведінки одне від одного, яка грунтується на ідеалізації, відповідно до якої мотив «для того, щоб» одного 3 них слугував мотивом «тому, що» Іншого. Прикладом такої взаємозумовленості мотивів слугує постановка запитання, очікування відповіді на це запитання від співрозмовника, і власне сформульована відповідь. Так, ставлячи запитання, співрозмовник очікує, що «Інший» зрозуміє запитання і наддасть відповідь, при тому зміст самої відповіді неважливий; формулювання запитання і очікування відповіді від партнера є мотивом «для того, щоб», тоді як розуміння цього запитання «Іншим» $є$ «тому, що» мотивом відповіді. Таке взаємовідношення мотивів є досвідновизначеним під час практики, адже комунікація передбачає, що постановка запитання так чи інакше викликає реакцію і очікування відповіді від співрозмовників. «У кожній ситуації у якій я зустрічаю іншого, я привношу мій запас знання, тобто седиментації попередніх одиничних досвідів. Цей запас знання включає, звичайно, переплетіння типізацій людей взагалі, їхні типово-людські мотивації, зразки дій, ієрархії планів тощо. Він включає моє знання про схеми вираження і схеми тлумачення, та моє знання об'єктивної системи знаків, особливо мови. Цьому загальному знанню, своєю чергою, підпорядковане знання мотивацій, дій, схем вираження, тощо, особливих типів людей, наприклад, чоловіків і жінок, молодих і старих, здорових і хворих, батьків i матерів, друзів i ворогів, американців i китайців» [5, с. 79].

Таким чином, оскільки люди є залученими до процесу комунікації, вони здатні розуміти інших людей, їх дії і поведінку тільки у тому випадку, якщо поставлять себе на місце «Іншого», зможуть уявити, що зроблять те саме, перебуваючи у тій самій ситуації, керовані тими самими мотивами «для того, щоб» і орієнтовані на ті самі, що й «Інший», мотиви «тому, що».

Сучасні розробки концепції «Іншого» містять дослідження 3 еволюційної біології, антропології, психології, неврології та психіатрії. Вони поглиблюють розуміння того, які механізми людської 
свідомості зумовлюють ті чи інші соціальні взаємозв'язки. Окремі дослідники вивчають механізми соціального пізнання, розкриваючи значення успішної взаємодії з іншими у соціальному світі. Вони зосереджуються на ідеї самопізнання через відношення до «Інших» у різних процесах, від емпатії до членства в групі.

Хайді Келлер застосовує міжкультурний підхід щодо розвитку розуміння себе та «Інших». Вчена визначає два ключові аспекти соціальних взаємовідносин: автономія та спорідненість як шляхи втілення соціалізації. Власне, розуміння автономії та спорідненості соціалізується на основі повсякденного досвіду та щоденного життя від народження. У своїй науковій роботі Келлер вирізняє два шляхи розвитку, які підкреслюють різні концепції автономії та спорідненості. Вони є способами пристосування до різних контекстів навколишнього середовища 3 відмінними можливостями та обмеженнями. Спираючись на приклади німецьких дітей середнього класу та дітей сільськогосподарських фермерів 3 ПівнічноЗахідного Камеруну, вчена обгрунтовує, як виховання дітей може змусити мати більш автономне або більш реляційне розуміння своïx стосунків з «Іншими» уже у дорослому віці. «Так, діти середнього класу, соціалізовані в напрямку психологічної автономії, тобто першості власних індивідуальних намірів та переконань, що дає можливість визначити спорідненість як психологічну конструкцію» [6]. Підготовка до життя у конкурентному світі «Інших» грунтується на індивідуальній психологічній автономії з урахуванням побажань, намірів та уподобань індивідів. Тоді як, «діти фермерів соціалізовані в бік ієрархічної спорідненості, тобто позиціонування себе в ієрархічній структурі соціальної системи, що дає визначення автономії як заснованої на відповідальності та зобов'язаннях» [6]. У такому разі підготовка до життя у невеликих селах грунтується на ієрархічному взаємозв'язку, де послух і повага становлять основу відповідальних дій. Ця самостійність дій, водночас, заснована на індивідуальних рішеннях та відповідальності. Саме ж дитинство вчена аналізує як культурну лінзу, з допомогою якої можна вивчати різні спектри соціалізації. Келлер пропонує різні стратегії виховання, спрямовані на підтримку цих різних цілей соціалізації у німецьких та євроамериканських батьків, з одного боку, та фермерів 
$3 \overline{\text { Північно-Західного Камеруну - } 3 \text { іншого. Підсумком слугує ви- }}$ сновок про те, що потрібні різні шляхи для розуміння людської психології з глобальної точки зору.

Автори Жан Декеті, Інбал Бен-Амі Бартал, Флорина Узефовськи та Аріель Кнафо-Ноам у праці «Емпатія як рушій просоціальної поведінки: нейро-поведінкові механізми у всіх видів» виокремлюють тему співпереживання та використовують інтегративний підхід до вивчення процесу взаємодії та розуміння «Інших». Вчені відзначають, що емпатія відображає природну здатність сприймати та бути чутливими до емоиійних станів інших людей у поєднанні 3 мотивацією піклуватися про їх добробут. Емпатія набула свого розвитку завдяки піклуванню батьків про своїх дітей та існуванню тісних взаємозв'язків і взаємозалежності між членами єдиної групи. «Здатність співчувати як тваринам, так і людям опосередковує просоціальну поведінку, коли чутливість до лиха інших людей поєднується 3 прагненням до їхнього добробуту. Порушення або нетиповий розвиток нервових ланцюгів, які обробляють сигнали дистрессу та інтегрують їх зі значенням рішення, призводить до ігнорування інших, як це має місце при психопатії» [7]. Вчені доходять висновку, що розуміння процесів, закладених у джерела емпатії, може сприяти лікуванню розладів соціальної взаємодії.

Отже, концепція комунікації, що сформувалася у філософії «ншого», знаходить своє визначення у різноманітних напрямах, школах і окремих вченнях філософів, які вкладають у дану категорію власний сенс і теоретичне обгрунтування. Спектр ролі комунікації з «Іншим» варіюється від персоналістської філософії з іiі орієнтацією на особистісну, індивідуальну основу спілкування - до феноменологічної соціології, яка зорієнтована на формування соціальних зв'язків на основі комунікації. У контексті персоналістської філософії визначальними для взаємовідносин є відкритість, чутливість, небайдужість, відповідальність, розуміння цінності іншої особистості. Значення дискурсу, сформованого на основі таких цінностей, полягає у розкритті особистостями раніше невідомих, неусвідомлених і незрозумілих один для одного світоглядних орієнтирів і має своїм результатом порозуміння. Проект феноменологічної соціології відкриває критерії інтерпретації чуттєвих даних іншої особистості на підставі образу, поведінки, життєвого досві- 
ду. Оцінювання «Іншого» як самого себе і себе як «Іншого», самоідентифікація, визнання за «Іншим» його «я», укоріненості і незамінності іншої людини засвідчує рівність учасників комунікації на соціальному рівні. У повсякденних практиках, соціальних діях й інтеракціях «Інший» постає необхідною стороною діалогічних взаємовідносин. У цілому, здійснення комунікації неможливе без визнання права «Іншого» на відмінності й особливості, усвідомлення його як рівноцінного партнера комунікації. Комунікативний простір, таким чином, постає як сфера діяльності, що поєднує у собі взаємозв'язки внутрішніх мотивів і особистісних установок індивіда із загальними цінностями й ідеалами й нормами інших людей. Перспектива дослідження обраної проблеми охоплює сучасні розробки концепції «Іншого», які поглиблюють розуміння того, що такі механізми соціального пізнання, як емпатія чи членство у групі, розкривають значення успішної взаємодії з іншими у соціальному світі.

\section{ЛITЕРАТУРА}

1. Бубер М. Два образа веры / ред. П. С. Гуревич, С. Я. Левит, С. В. Лёзов. Москва : Республика, 1995. 464 с.

2. Левинас Э. Тотальность и Бесконечное. СПб. : Университетская книга, 2000. $416 \mathrm{c.}$

3. Рікер П. Сам як інший / пер. $з$ фр. В. Андрушко. Київ : Дух і літера, 2002. 458 c.

4. Сартр Жан-Поль. Буття і ніщо: Нарис феноменологічної онтології / пер. $з$ фр. В. Лях, П. Таращук. Київ : Видавництво Соломії Павличко «Основи», 2001. 854 с.

5. Шюц Альфред. Структури життєсвіту / пер. 3 нім. та післямова В. Кебуладзе. Київ : Український Центр духовної культури, 2004. 560 с.

6. Keller H. Psychological autonomy and hierarchical relatedness as organizers of developmental pathways. URL: https://www.ncbi. nlm.nih.gov/pmc/articles/PMC4685516

7. Empathy as a driver of prosocial behaviour: highly conserved neurobehavioural mechanisms across species. URL: https://www.ncbi. nlm.nih.gov/pmc/articles/PMC4685523 


\section{REFERECES}

Buber, M. (1995). Two of the image of the faith. Moscow: Republic. 464 p. [In Russian].

Levinas, E. (2000). Totality and the Infinity. St. Petersburg: University book. 416 p. [In Russian].

Ricœur, P. (2002). Oneself as Another. Kyiv: Spirit and Letter. 458 p. [In Ukrainian].

Sartre, Jean-Paul. (2001). Being and Nothing: An Essay on Phenomenological Ontology. Kyiv: Solomiya Pavlychko Publishing House "Fundamentals". 854 p. [In Ukrainian].

Schutz, Alfred. (2004). Structures of the Life-World. Kyiv: Ukrainian Center for Spiritual Culture, 2004. 560 p. [In Ukrainian].

Keller, H. Psychological autonomy and hierarchical relatedness as organizers of developmental pathways. Retrieved from: https://www.ncbi .nlm.nih.gov/pmc/articles/PMC4685516

Empathy as a driver of prosocial behaviour: highly conserved neurobehavioural mechanisms across species. Retrieved from: https://www.ncbi.nlm.nih.gov/pmc/articles/PMC4685523

\section{Iryna Zhovtonoh}

Post-Graduate Student, Centre For Humanitarian Education of The National Academy of Sciences of Ukraine; Kyiv, Ukraine; e-mail: irazhovtonoh@gmail.com; ORCID: https://orcid.org/0000-0002-9702-5903

\section{Place and meaning of communication in the philosophy of the other}

\section{Abstract}

The article studies the sources of the concept of communication, which are formed in the philosophy of «the Other». The peculiarities of constructing a discourse with "the Other» on the basis of the philosophy of dialogue are revealed. Interaction with «the Other» is carried out through the articulation of «the Other», the appeal and response to the appeal of «the Other», intentionality, reflexivity, mutual orientation. The specifics of orientation on the personal, 
individual basis of communication carried out in personal philosophy are determined. The concepts of openness, sensitivity, indifference, responsibility are crucial for building communication in personal philosophy. The criteria for interpreting the sensory data of «the Other» are image, behavior, accumulated life experience, they are developed in sociological phenomenology. The formation of social ties is based on the perception of motives, behavior and reactions of «the Other» in everyday life. The mechanisms of social cognition, successful interaction with "Others» and self-knowledge are revealed in modern theories of communication. They deepen the understanding of social cognition through the relationship with «the Other» in various processes, from empathy to group membership. Communicative space is studied as a sphere of activity that combines the relationship of internal motives and personal attitudes of the individual with the common values, ideals and norms of others. The prospect of researching the chosen problem covers the current development of the concept of «the Other», which deepens the understanding that such mechanisms of social cognition as empathy or group membership, reveal the importance of successful interaction with others in the social world.

Keywords: communication with the Other, intentionality, reflexivity, interchangeability of points of view, rootedness, self-identification, empathy. 